\title{
Preserving our sky heritage
}

\author{
Michel Bonavitacola ${ }^{1}$ \& Alain Le Gué (1,2 $^{1}$ \\ ${ }^{1}$ Association LICORNESS \\ 21 val de Frosine, 31180 Saint Genies Bellevue, France \\ email:mibvc@wanadoo.fr \\ ${ }^{2}$ Association Nationale pour la Protection du Ciel et de l'Environnement Nocturne, \\ c/o Société Astronomique de France, \\ 3 rue Beethoven, 75016 Paris, France \\ alain.legue@wanadoo.fr
}

\begin{abstract}
We briefly relate the story of the fight against light pollution in France and make a projection into the future. Following the steps of Jean Kovalevsky who was the initiator of the protection of the astronomical sites in France, a few French amateur astronomers began the fight against light pollution in the 1990s. After a first conference for the night environmental protection in 1995 in Rodez, the second conference in 1998 creates the national association which will become in 2007 the National association for the Protection of the Sky and the Night Environment (ANPCEN). In 2008 light pollution is formally identified, by law, as a problem. Since 2005 the LICORNESS association continues to promote research on the impacts of light on the biotopes while protecting the astronomical sites.
\end{abstract}

Keywords. light pollution, heritage, research

\section{World time line}

- June 51972 First regulation in the city of Tucson, Arizona.

- September 1976 IAU Committee No. 50 adopts a resolution for the protection of astronomical sites.

- 1980 The International Commission on Illumination, publishes recommendations for reducing luminous haloes around observatories. Jean Kovalevsky publishes a report on The protection of astronomical and geophysical observatories.

- 1988 David L. Crawford founds the International Dark Sky Association (IDA).

- June 1992 Conference on the adverse impacts on the environment in astronomy at the UNESCO headquarters in Paris. The night sky, with its beautiful stars and its message of our place in the universe is a precious treasure for humakind (page XVII). It is also noted that observatories are part of our cultural heritage and preserve (page XIX).

- August 2001 Publication of the first World Atlas of Light Pollution by by P. Cinzano, F. Falchi and C.D. Elvidge.

\section{France time line}

- Early 1983 First theoretical work by the Association Astronomique de la Vallée.

- 1986 Report by Jean Kovalevsky The protection of astronomical sites" published in l'Astronomie.

- March 1991 First Information campaign on Light Pollution by the Fédération d'Astronomie Populaire Amateur du Midi.

- Mid 1991 Benoît Rousseau's Editorials in the journal of the SAF Observation \& Travaux. 
- Early 1992 Several associations of amateur astronomy publish a Charter for the Night Sky Protection. It will appear in many magazines.

- September 1992 First discussion on Light Pollution at the Société Astronomique de France.

- 1993 Laurent Corp, following a paper in Sky \& Telescope, attempts the first measure of the sky background luminance.

- January 1994 Michel Bonavitacola, Raymond Mosser and Guy Hoffer create the Centre for the Protection of the Night Sky (CPCN in French) near Toulouse.

- March 1994 The SAF establishes a National Committee for the Night Sky Protection (CNPCN).

- June 1994 Complete dossier in l'Astronomie. Jean-Michel Lazou, an elected representative in a French city council, describes his attempts to reduce light pollution in the city of Reichstett (Alsace).

- Early 1995 The committee liaises with the Association Française d'Astronomie (AFA) and the ANSTJ ("Planète Science"). Lighting engineers of the Association Française de l'Eclairage attend the meeting.

- 1996 Rationale for preserving the night sky, published in the journal l'Astronomie.

- October 1995 First National Conference for the Night Sky Protection in Rodez.

- October 1997 Technical meeting on light and light pollution at Chinon.

- December 1996 Launch of "Operation Atlas 97" in the magazine PULSAR.

- May 1998, Rencontres du Ciel et de l'Espace organised by AFA, with representatives from Switzerland, Germany, Great Britain, Spain and Italy, to discuss light pollution. First European Symposium for Night Sky Protection for IDA.

- October 1998 Second Conference at Rodez. Presentation of the first light pollution modeling ever done in France. The Association Nationale pour la Protection du Ciel Nocturnee (ANPCN) replaces the National Committee for the night sky Protection.

- March 1999 Formal establishment of ANPCN.

- Fall 1999 Release of its biannual newsletter called SOS (Save Our Sky).

- August 2001 During the national operation of the Nuit des Etoiles (Starry nights), an estimation of the Observation site' sky quality is made.

- September 2004 ANPCN meeting held in Paris, the fourth European Symposium for the Night Sky Protection.

- June 2006 CPCN officially became Licorness: Light Control brightness Night Sky Survey Environment, with the declared goal of filling the gap in French studies on light pollution and its impact on the environment.

- Late 2006 Michel Bonavitacola resumed an idea by Yvan Dutil to create a Dark Sky Reserve in France.

- October 2007 The Association Nationale pour la Protection du Ciel et de l'Environnement Nocturne (ANPCEN) replaces the Association Nationale pour la Protection du Ciel Nocturne.

- October 2008 Establishment of the association PIRENE, created for the approved project of the International Year of Astronomy for an International Sky Reserve at Pic du Midi de Bigorre.

- September 2008 The Minister Nathalie Kosciusko-Morizet organises, in association with the City of Meudon, Observatoire de Paris, ADEME and the National Museum of Natural History, a picnic at night at the site of the Observatoire de Meudon. At long last, light pollution is recognised in France as a cultural and environmental problem!

- October 2008 The French National Assembly passes the law called "Grenelle 1" by 526 votes to 4 against and 21 abstentions which contains in particular Article 36 "Emissions of artificial light could be dangerous or cause excessive disturbance to people, 
wildlife, flora and ecosystems, causing energy waste or preventing the observation of the night sky will subject to measures of prevention, suppression or limitation".

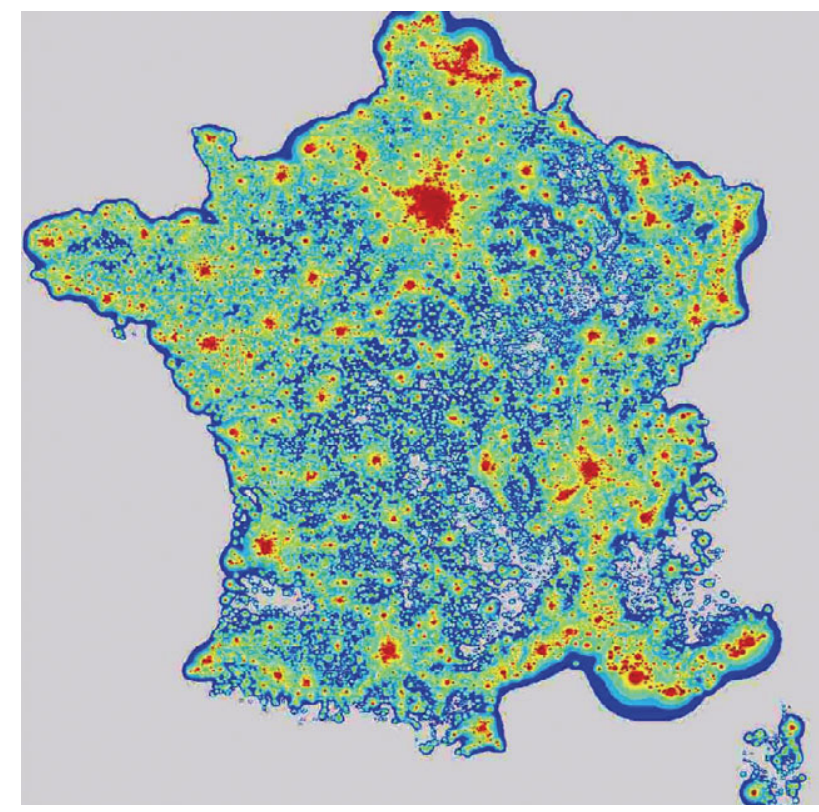

Figure 1. First map of simulated light pollution in France. (c) Association LICORNESS.

\section{Projects and measurements campaigns}

During the 2009 International Year of Astronomy 2009, we organised: (1) project "PIC du MIDI International Dark Sky Reserve" (see www.pirene.eu), and (2) the Third National Conference for the protection of the sky and night environment, in Fleurance (October 2009, see http://www.fermedesetoiles.com/congres-pollution-lumineuse. php).

In addition, the LICORNESS association along with the Société Astronomique de France, the Association Aéronautique \& Astronautique de France and PIRENE, will continue the measures of quality of the sky through the constellation Earth and ATLAS projects. These measures are designedfor an assessment in order to safeguard astronomical sites and identify areas for protection. The campaign of measures will include panoramic viewpoints (as at Pic du Midi), ground-based measures, and also from space (Space Station, satellites). This ATLAS project will use both simple and sophisticated measures: estimating the visual magnitude limit, counting stars, measures to SQM and photometers. The project will also serve to quantify the results of a possible implementation of the law restricting light pollution. Some results of ATLAS 97 and on constellation Earth are available at the web site of Association LICORNESS (www.astrosurf.com/licorness).

\section{References}

McNally, D. (ed) 1994, The Vanishing Universe (Cambridge: Cambridge University Press) 